Tropical Journal of Pharmaceutical Research June 2021; 20 (6): 1233-1239

ISSN: $1596-5996$ (print); 1596-9827 (electronic)

(C) Pharmacotherapy Group, Faculty of Pharmacy, University of Benin, Benin City, 300001 Nigeria.

Available online at http://www.tjpr.org

Original Research Article

http://dx.doi.org/10.4314/tjpr.v20i6.20

\title{
Sensitive and rapid spectrophotometric methods for sertraline monitoring in pharmaceutical formulations
}

\author{
Ali Sayqal ${ }^{1}$, Amr Lotfy Saber ${ }^{1,2 *}$ \\ ${ }^{1}$ Chemistry Department, Faculty of Applied Science, Umm Al-Qura University, Makkah, Saudi Arabia, ${ }^{2}$ Chemistry Department, \\ Faculty of Science, Zagazig University, Zagazig, Egypt \\ *For correspondence: Email: alshefny@yahoo.com
}

Sent for review: 01 January 2021

Revised accepted: 17 May 2021

\begin{abstract}
Purpose: To develop simple, rapid, and selective spectrophotometric methods for the assay of sertraline in a pharmaceutical formulation.

Method: These methods depend on the formation of colored ion-pair complexes between the drug and five different reagents; methyl blue (MB), bromophenol red (BPR), methyl green (MG), phenol red (PR), and methyl orange $(\mathrm{MO})$ in $B-R$ buffer solutions of $\mathrm{pH}$ ranging from $2.0-8.0$. The colored products were measured at $668,747,647,717$, and $553 \mathrm{~nm}$, respectively.

Results: The calibration graphs were linear over the concentration range of $2-18 \mu \mathrm{g} / \mathrm{mL}$ for $M B$ and $B P R$, and $2-16 \mu \mathrm{g} / \mathrm{mL}$ for $M G, P R$, and $M O$. In all cases, the reaction stoichiometry was 1:1. The proposed methods were successfully applied to solid-dose pharmaceutical preparations (tablets). Excipients in the commercial formulation did not interfere with the analysis.

Conclusion: The investigated methods can be recommended for routine analysis and quality control where cost-effectiveness, high specificity of the analytical technique, and time are of great importance.

Keywords: Sertraline, Ion pair complex, Spectrophotometry, Pharmaceutical

This is an Open Access article that uses a funding model which does not charge readers or their institutions for access and distributed under the terms of the Creative Commons Attribution License (http://creativecommons.org/licenses/by/4.0) and the Budapest Open Access Initiative (http://www.budapestopenaccessinitiative.org/read), which permit unrestricted use, distribution, and reproduction in any medium, provided the original work is properly credited.

Tropical Journal of Pharmaceutical Research is indexed by Science Citation Index (SciSearch), Scopus, International Pharmaceutical Abstract, Chemical Abstracts, Embase, Index Copernicus, EBSCO, African Index Medicus, JournalSeek, Journal Citation Reports/Science Edition, Directory of Open Access Journals (DOAJ), African Journal Online, Bioline International, Open-J-Gate and Pharmacy Abstracts
\end{abstract}

\section{INTRODUCTION}

Depression is one of the most common mental diseases in the world which has significantly negative effects on the whole life of patient and may also resulted in self-injury and suicide [1]. Presently, the selective serotonin reuptake inhibitors (SSRIs) such as sertraline and fluoxetine have become one of the most frequently prescribed drugs for depression treatment [2]. However, these drugs have many toxic side effect including gastrointestinal disturbance [3]. It has been reported that the daily oral doses of sertraline is in the range of 50 - $200 \mathrm{mg}$ and its steady state plasma concentration is from $55-250 \mathrm{ng} / \mathrm{mL}$ [2]. In addition, studies have investigated the level of sertraline in several biological materials such as serum, plasma, saliva and human milk. The level of sertraline in saliva and human milk was found to range between 5 to $500 \mathrm{ng} / \mathrm{mL}$, whereas in the case of plasma and serum, values reported were $(0.5-1000 \mathrm{ng} / \mathrm{mL})$ and $(2-400 \mathrm{ng} / \mathrm{mL})$ respectively [4-9]. Furthermore, the presence of sertraline in waste water at very low concentration has also been reported [10]. The 
chemical structure of sertraline is shown in Figure 1.<smiles>CN[C@H]1CC[C@@H](c2ccc(Cl)c(Cl)c2)c2ccccc21</smiles>

Figure 1: Chemical structure of sertraline

Several analytical techniques have been described for the detection of sertraline in various samples including spectrofluorimetry [11,12], capillary electrophoresis [13], gas chromatography mass spectrometry (GC-MS) [14-16], liquid chromatography (LC) [17] and high performance liquid chromatography (HPLC) [18]. However, most of these procedures have complicated and expensive processes. Therefore, the aim of the present work is the creation of a simple, rapid, accurate, and selective procedure for the determination of sertraline in pure powder and dosage forms.

\section{EXPERIMENTAL}

\section{Materials and reagents}

All reagents and materials used were of analytical reagent grade. Sertraline reference standard was kindly provided by Spimaco (Saudi Pharmacutical Industries and Medical Appliances Corp). Stock solutions. A series of universal buffer solutions Britton-Robinson (B-R) were prepared by the following standard method [24]. A stock solution of sertraline $(100 \mu \mathrm{g} / \mathrm{mL})$ was prepared using least amount of doubly distilled water to dissolve $10 \mathrm{mg}$ of pure drug then transferred into a $100 \mathrm{~mL}$ measuring flask, and then the solution was diluted with water up to the mark. Working solutions of the drug were prepared by further dilution with the same solvent. Standard solutions $\left(1.0 \times 10^{-3} \mathrm{M}\right)$ of the reagents (methyl blue $(\mathrm{MB})$, bromophenol red (BPR), methyl green (MG), phenol red (PR), and methyl orange (MO)) were prepared using few drops of ethanol by transferring accurately weighted of acid dyes into $250 \mathrm{~mL}$ measuring flasks separately, and then diluted to the mark with appropriate solvent.

\section{Apparatus}

A UV-visible spectrophotometer model Shimadzu UV-vis with $10 \mathrm{~mm}$ quartz cells was utilized for spectrophotometric determinations. The $\mathrm{pH}$ measurements were performed by using a $\mathrm{pH}$ meter, model HI 8014, HANNA Instruments (Italy).

\section{Assay procedure for pure drug}

Aliquots of sertraline solution containing up to $0.18 \mathrm{mg} \mathrm{mL}^{-1}$ were transferred into a series of 10 $\mathrm{mL}$ calibrated funnels and then a volume of 5.0 $\mathrm{mL}$ of buffer solutions of varying $\mathrm{pH}$ values $(5.0$, 3.0, 5.0, 8.0 and 3.0) were added after addition of $1.0 \mathrm{~mL}$ of reagent solutions (MB, BPR, MG, $P R$ and $M O)$ with a fixed concentration (1mM). Thereafter, the aqueous solutions were completed to mark using methanol and the solutions allowed to stand for $30 \mathrm{~min}$. at $25 \pm 1^{\circ} \mathrm{C}$. Finally, the absorbance was measured at the wavelength of maximum absorption over 400$800 \mathrm{~nm}$ against a blank reagent (Table 1). The reagent blank solution contained methanol and was prepared in the same manner but without sertraline. The standard calibration graph was used to calculate the drug concentration under the same identical conditions.

\section{Assay procedure for tablets}

In order to analyze sertraline in a commercial solid dose formulation, ten commercial tablets of Lustral (50 mg sertraline hydrochloride) tablets were weighed and powdered. Certain amount of the powder equivalent to $10 \mathrm{mg}$ of the investigated drug was weighed and transferred into a $100 \mathrm{~mL}$ volumetric flask containing bidistilled water, and then the suspended solution was shaken for about $10 \mathrm{~min}$. This was followed by filtration through a Whatman filter paper No. 40 to remove insoluble matter. The remaining filtrate was diluted with bidistilled water to the mark. The general procedure described above can be successfully applied to assay of sertraline concentration in tablets using blank solution. A standard additions technique was also used to confirm precision and accuracy.

\section{RESULTS}

\section{Spectral characteristics and optimization conditions}

The ion-pair spectrophotometry has received a considerable attention for quantitative analysis of many pharmaceutical compounds [19]. It behaves as a strong electron acceptor due to the presence of the strong electron withdrawing sulphonic acid group conjugated with the aromatic ring system [20,21]. The positively charged drug forms with anionic reagents like $\mathrm{MB}$, ion-association complex. The two oppositely charged ions form a drug-dye complex, behaving 
as a single unit held together by an electrostatic force of attraction. So, sertraline forms ion-pair complexes with acidic dyes such as MB, BPR, $M G, P R$ and $M O$ in acidic medium. The absorption spectra of the complexes were measured against blank solution containing identical reagent concentration between 350 and $800 \mathrm{~nm}$, (Figure 2). The maximum absorption values $\left(\lambda_{\max }\right)$ of the different complexes are shown in Table 1.

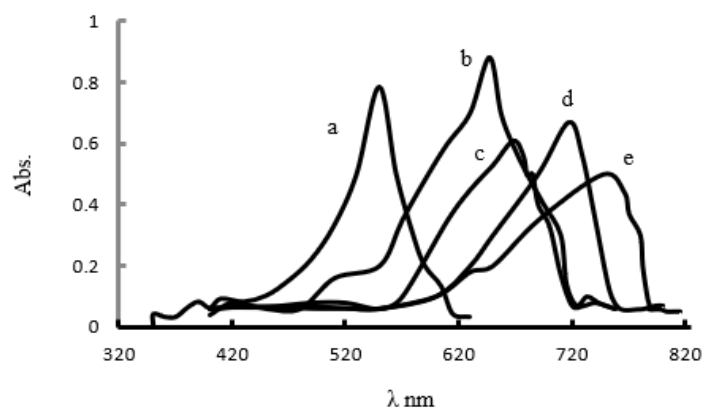

Figure 2: Absorption spectra of ion-pair complexes formed with $10 \mu \mathrm{g} / \mathrm{mL}$ ST. a=ST-MO, b=ST-MG, c=ST$M B, d=S T-P R, e=S T-B P R$

Optimum reaction conditions for quantitative determination of ion-pair complexes were determined by various preliminary experiments. The effect of $\mathrm{pH}$ was studied using different buffers such as $\mathrm{NaOAc}-\mathrm{AcOH}(\mathrm{pH}=3.65-5.50)$, $\mathrm{KHPh}-\mathrm{HCl}(\mathrm{pH}=2.22-3.58), \mathrm{NaOAc}-\mathrm{HCl}(\mathrm{pH}=$ 2.05 - 4.82), and $\mathrm{B}-\mathrm{R}$ buffer $(\mathrm{pH}=2.0-9.0)$ for the formed ion-pair complexes. The maximum color intensities were observed in B-R buffer solutions of acidic and weak basic values (Figure $3 \&$ Table 1). The effect of the reagents concentrations on the color intensities of the different complexes was examined at constant drug concentration using different reagent concentrations at the optimum $\mathrm{pH}$.

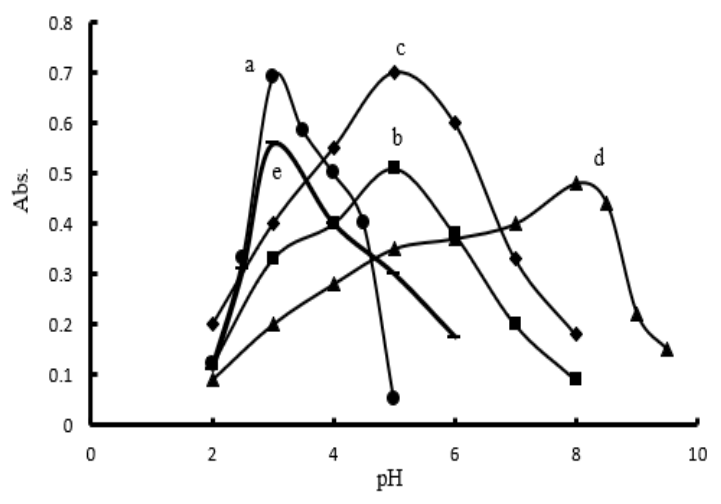

Figure 3: Effect of $\mathrm{pH}$ on the absorbance of ion-pair complexes formed with $10 \mu \mathrm{g} / \mathrm{mL}$ ST. a=ST-MO, $b=S T-M G, c=S T-M B, d=S T-P R, e=S T-B P R$

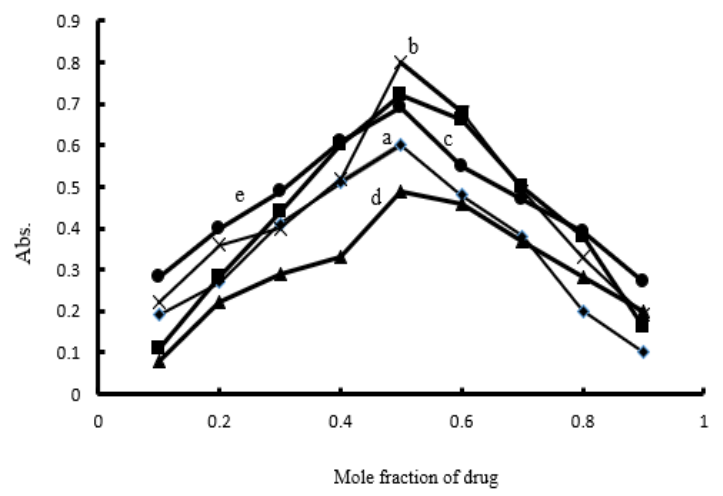

Figure 4: Continuous variation plots for the ion-pair complexes of $10 \mu \mathrm{g} / \mathrm{mL}$ ST. a=ST-MO, b=ST-MG, $\mathrm{c}=\mathrm{ST}-\mathrm{MB}, \mathrm{d}=\mathrm{ST}-\mathrm{PR}, \mathrm{e}=\mathrm{ST}-\mathrm{BPR}$

Table 1: Assay results for sertraline

\begin{tabular}{|c|c|c|c|c|c|}
\hline \multirow{2}{*}{ Parameter } & \multicolumn{5}{|c|}{ Sertraline } \\
\hline & MB & BPR & MG & PR & MO \\
\hline $\mathrm{pH}$ & 5.0 & 3.0 & 5.0 & 8.0 & 3.0 \\
\hline Solvent & ethanol & ethanol & ethanol & ethanol & ethanol \\
\hline$\lambda_{\max }$ & 668 & 747 & 647 & 717 & 553 \\
\hline Molar ratio (Drug-HCl : Dye) & $1: 1$ & $1: 1$ & $1: 1$ & $1: 1$ & $1: 1$ \\
\hline Beer's law limits $\left(\mu \mathrm{g} \mathrm{ml}^{-1}\right)$ & $2.0-14$ & $2.0-16$ & $2.0-14$ & $2.0-14$ & $2.0-18$ \\
\hline Molar absorptivity $\left(\mathrm{L} \mathrm{mol}^{-1} \mathrm{~cm}^{-1}\right)$ & $1.74 \times 10^{4}$ & $1.68 \times 10^{4}$ & $1.84 \times 10^{4}$ & $1.87 \times 10^{4}$ & $1.78 \times 10^{4}$ \\
\hline Sandell's sensitivity $\left(\mathrm{ng} \mathrm{cm}^{-2}\right)$ & 17.5 & 18.2 & 16.7 & 16.4 & 17.2 \\
\hline Range of error $\%$ & $-0.76: 0.554$ & $-0.67: 0.56$ & $-0.66: 0.40$ & $0.43: 0.76$ & $-0.78: 0.88$ \\
\hline \multicolumn{6}{|l|}{ Regression equation ${ }^{*}$} \\
\hline Intercept & 0.050 & 0.023 & 0.036 & 0.034 & 0.032 \\
\hline Slope & 0.057 & 0.055 & 0.060 & 0.061 & 0.058 \\
\hline Correlation coefficient $(r)$ & 0.9927 & 0.9927 & 0.9971 & 0.9919 & 0.9921 \\
\hline t-value $(2.56)^{* *}$ & 1.38 & 1.67 & 1.44 & 1.55 & 1.87 \\
\hline $\mathrm{F}$ - value $(5.05)^{* *}$ & 2.88 & 3.85 & 3.67 & 2.66 & 3.21 \\
\hline $\operatorname{LOD}\left(\mu \mathrm{g} \mathrm{ml}^{-1}\right)$ & 0.6 & 0.7 & 0.5 & 0.6 & 0.8 \\
\hline $\mathrm{LOQ}\left(\mu \mathrm{g} \mathrm{ml}^{-1}\right)$ & 1.7 & 2.2 & 1.6 & 1.6 & 2.1 \\
\hline
\end{tabular}

${ }^{*} \mathrm{~A}=\mathrm{a}+\mathrm{bC}$, where $\mathrm{b}=$ slope, $\mathrm{a}=$ intercept and $\mathrm{C}$ is the concentration in $\mu \mathrm{g} \mathrm{mL}^{-1} ;{ }^{* *}$ Values in parentheses are the theoretical values for $\mathrm{t}$ - and $\mathrm{F}$ - values at $95 \%$ confidence limits and five degrees of freedom 


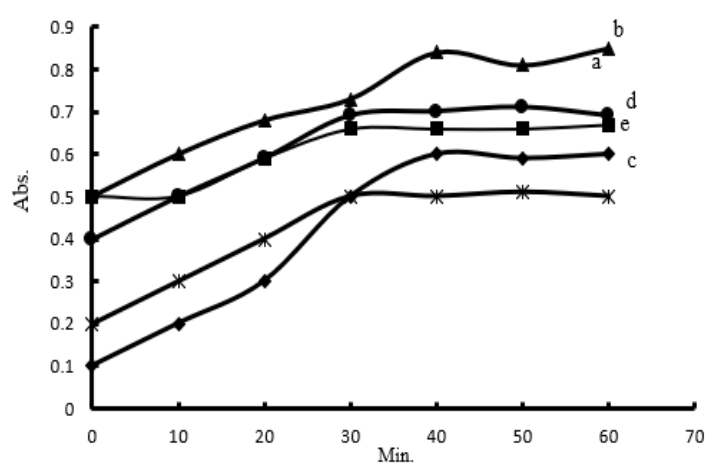

Figure 5: Effect of time on the formation of complexes between $S T$ with reagents. $a=S T-M O, b=S T-M G$, $\mathrm{c}=\mathrm{ST}-\mathrm{MB}, \mathrm{d}=\mathrm{ST}-\mathrm{PR}, \mathrm{e}=\mathrm{ST}-\mathrm{BPR}$

Constant absorbance values was obtained during shaking over a time period of 1.0-5.0 min. and hence a shaking time of $1.0 \mathrm{~min}$ was maintained throughout to facilitate ion pair complex formation. The effect of temperature was studied at different temperatures $(25,30,35$, $40,45^{\circ} \mathrm{C}$ ) for the formation of colored complexes. It was found that the colored species were stable up to $45^{\circ} \mathrm{C}$. At higher temperatures, the drug concentrations were found to increase due to volatile nature of the organic solvent, which cause an increase in the absorbance of the products. The colored species were found to be stable at room temperature in closed system.

\section{Stoichiometric relationship}

Job's method of continuous variation [20] was used for determining the molar ratio of drug (ST) to each of the reagents employed in the ion pair reactions. In these methods, the drug (ST) and analytical reagents (MB, BPR, MG, PR and MO) were prepared in the same concentration $(1.0 \mathrm{X}$ $\left.10^{-3} \mathrm{M}\right)$. Then a series of solutions was made by mixing different volumes of the drug and reagents. The total volume of the drug and reagents were kept constant in these solutions. Thereafter, the procedure was completed as same as the above-mentioned procedure. Finally, the absorbance was separately measured at the optimum wavelength for each complex. The absorbance was plotted against [ST]/[ST] + [dye] for Job's method and [dye]/ [ST] for mole-ratio method [23]. The obtained results indicated that $1: 1$ (drug : reagent) complexes were formed by these proposed methods (Figure 4).

The equilibrium of complex formation can be represented as Eq 1:

$\mathrm{STH}^{+}{ }_{(\text {aq. }}+\mathrm{R}^{-}$(aq.) $\rightleftharpoons \mathrm{STH}^{+} . \mathrm{R}^{-}$(aq.)

where, $\mathrm{STH}^{+}$and $\mathrm{R}^{-}$represent the protonated sertraline and the anion of the reagent, respectively. The subscript (aq.) refer to the aqueous phase. The spectrophotometric methods that are usually applied to determine the stoichiometric ratio of the complexes (Table 1).

The linear square treatment of the results is used to obtain Beer-Lambert law limits, Sandell's sensitivity, molar absorptivity, regression equations and correlation coefficients such as shown in Table 1.

Table 2: Determination of accuracy and precision of the methods on pure drug sample

\begin{tabular}{|c|c|c|c|c|}
\hline Procedure & 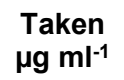 & $\begin{array}{c}\text { Recovery } \\
\%\end{array}$ & $\begin{array}{c}\text { RSD, } \\
\%\end{array}$ & $\begin{array}{c}\text { RE, } \\
\%\end{array}$ \\
\hline \multirow{3}{*}{ MB } & 20.0 & 100.11 & 0.168 & 0.55 \\
\hline & 30.0 & 99.68 & 0.104 & 0.47 \\
\hline & 40.0 & 99.85 & 0.156 & -0.76 \\
\hline \multirow{3}{*}{ BPR } & 20.0 & 100.24 & 0.127 & 0.56 \\
\hline & 30.0 & 99.55 & 0.112 & -0.67 \\
\hline & 40.0 & 99.38 & 0.177 & 0.48 \\
\hline \multirow{3}{*}{ MG } & 20.0 & 100.16 & 0.198 & -0.64 \\
\hline & 30.0 & 99.87 & 0.167 & 0.40 \\
\hline & 40.0 & 99.88 & 0.143 & -0.66 \\
\hline \multirow{3}{*}{ PR } & 20.0 & 99.83 & 0.188 & 0.43 \\
\hline & 30.0 & 99.66 & 0.143 & 0.76 \\
\hline & 40.0 & 99.30 & 0.146 & 0.63 \\
\hline \multirow{3}{*}{ MO } & 20.0 & 100.35 & 0.177 & 0.88 \\
\hline & 30.0 & 99.23 & 0.188 & -0.78 \\
\hline & 40.0 & 100.38 & 0.169 & -0.51 \\
\hline
\end{tabular}

*Average of six determinations 
Table 3: Content of sertraline in its formulation using the proposed and HPLC methods.

\begin{tabular}{|c|c|c|c|c|c|c|c|c|}
\hline \multirow{2}{*}{ Sample } & \multirow[b]{2}{*}{ Method } & \multirow{2}{*}{$\begin{array}{c}\text { Manifested } \\
\text { by }\end{array}$} & \multirow{2}{*}{$\begin{array}{l}\text { Taken } \\
\mu \mathrm{g} / \mathrm{ml}\end{array}$} & \multirow{2}{*}{$\begin{array}{l}\text { Added } \\
\mu \mathrm{g} / \mathrm{ml}\end{array}$} & \multicolumn{2}{|c|}{ Found $^{*}$} & \multirow{2}{*}{$\begin{array}{c}\text { Recovery } \\
\%\end{array}$} & \multirow{2}{*}{$\begin{array}{c}\text { S.D. } \\
\%\end{array}$} \\
\hline & & & & & Official & Proposed & & \\
\hline & $\mathrm{MO}$ & & 10.0 & & 9.98 & 10.08 & 100.80 & 0.95 \\
\hline Lustral $^{\mathrm{TM}}$ & & ${ }^{* *}$ Pfizer & & 2.0 & 12.10 & 12.07 & 100.58 & 1.22 \\
\hline \multirow[t]{13}{*}{$50 \mathrm{mg} / \mathrm{tabl \epsilon}$} & & & & 4.0 & 14.04 & 13.96 & 99.71 & 0.83 \\
\hline & MG & & 10.0 & & 9.96 & 10.01 & 100.10 & 0.73 \\
\hline & & & & 2.0 & 11.95 & 12.02 & 100.16 & 0.65 \\
\hline & & & & 4.0 & 13.93 & 14.07 & 100.50 & 0.96 \\
\hline & MB & & 10.0 & & 10.05 & 9.97 & 99.70 & 0.65 \\
\hline & & & & 2.0 & 11.98 & 11.96 & 99.66 & 1.13 \\
\hline & & & & 4.0 & 14.02 & 13.98 & 99.85 & 1.23 \\
\hline & BPR & & 10.0 & & 9.95 & 9.98 & 99.80 & 0.73 \\
\hline & & & & 2.0 & 11.92 & 12.03 & 100.25 & 0.81 \\
\hline & & & & 4.0 & 13.96 & 14.04 & 100.28 & 0.98 \\
\hline & PR & & 10.0 & & 9.94 & 9.98 & 99.71 & 1.41 \\
\hline & & & & 2.0 & 12.06 & 11.96 & 99.66 & 0.87 \\
\hline & & & & 4.0 & 13.98 & 13.96 & 99.71 & 0.93 \\
\hline
\end{tabular}

${ }^{*}$ Mean of six determinations

In order to calculate the precision and accuracy of the five systems, six replicates of three different concentrations of sertraline were prepared and analyzed. Therefore, the ion-pair formations were utilized successfully for their quantification. The accuracy and precision of the investigated methods were calculated using percent relative error (RE \%) and percent relative standard deviation (RSD \%) (Table 2). The accuracy and precision data showed that the investigated methods have acceptable reproducibility and repeatability. The percent relative standard deviation (RSD \%) and recoveries were found to vary over acceptable ranges (Table 2 ).

Limit of detection (LOD) and limit of quantification (LOQ) [23] are defined as the lowest amount which can be detected and accurately quantified (Table 1), respectively. LOD and LOQ were calculated using Eqs 2 and 3.

$$
\begin{aligned}
& \mathrm{LOD}=3.3 \mathrm{SD} / \mathrm{S} \\
& \mathrm{LOQ}=10 \mathrm{SD} / \mathrm{S}
\end{aligned}
$$

where $S D$ is the standard deviation of the blank and $S$ is the slope of the standard curve.

\section{Effect of excipients}

It was observed that the common excipients and other additives such as talc, glucose, sulfate, starch, magnesium stearate, phosphate, acetate, and dextrose did not interfere with the detection at the different concentration found in the dosage form.

The optimum reaction time was tested by measuring the absorbance of the developing colored complexes at different time intervals for all the methods. Complete and stable formation of colored products needs $30,30,30,40$ and 40 min for $M O, P R, M B, M G$ and $B P R$, respectively (Figure 5).

\section{DISCUSSION}

The investigated methods have been applied successfully to the quantification of sertraline in pharmaceutical formulation. The HPLC method [22] was used to compare the results obtained using the proposed methods (Table 3). For further confirmation, the test of the reliability and recovery of the proposed methods was applied using the standard addition method, since the ionpair formulations are stable for at least $24 \mathrm{~h}$. The high percentage recoveries show that the common excipients such as starch, talc, lactose, sulfate, dextrose, glucose, and phosphate, acetate, and magnesium stearate in pharmaceutical dosage forms of sertraline did not interfere with the analysis of the studied drug. 
The data obtained for the investigated methods were compared with the data obtained from HPLC method [22]. The calculated t-values and F-values did not exceed the theoretical ones at $95 \%$ confidence level [23]. Therefore, there is no significant difference between the HPLC method and investigated methods.

\section{CONCLUSION}

The investigated method has been successfully developed using simple procedures to determine the test drug in pure powder and dosage forms. The developed methods are sufficiently sensitive to permit detection down to $5.0 \mu \mathrm{g} / \mathrm{mL}$. The methods exhibit high reliability owing to the stability of the ion-pair complexes. The methods are simple, sensitive, accurate, precise and convenient. Therefore, it can be useful for quality control assay and routine analysis of the test drug in raw materials and tablets free of interference from excipients.

\section{DECLARATIONS}

\section{Acknowledgement}

The authors are grateful to Bouguerra Marouane Dhia Eddine for his help in completing the experiments.

\section{Conflict of interest}

No conflict of interest is associated with this work.

\section{Contribution of authors}

We declare that this work was done by the authors named in this article and all liabilities pertaining to claims relating to the content of this article will be borne by the authors.

\section{Open Access}

This is an Open Access article that uses a funding model which does not charge readers or their institutions for access and distributed under the terms of the Creative Commons Attribution License (http://creativecommons.org/licenses/by/ 4.0) and the Budapest Open Access Initiative (http://www.budapestopenaccessinitiative.org/rea d), which permit unrestricted use, distribution, and reproduction in any medium, provided the original work is properly credited.

\section{REFERENCES}

1. Dziurkowska E, Wesolowski M. Sertraline - isolation methods and quantitation in biological material, Psychiatria Polska 2018; 52: 997-1012.

2. Lotfi A, Manzoori JL, Mohagheghi A. Determination of sertraline in pharmaceutical and biological samples using 1, 10-phenanthroline-terbium probe and silver nanoparticles enhanced fluorescence. J. Luminescence 2017; 185: 132-140.

3. Boscha ME, Sanchez AJR, Rojas FS, Ojeda CB. Analytical methodologies for the determination of sertraline, J. Pharmaceut. and Biomed. Anal. 2008; 48:1290-1302.

4. Gjestad C, Westin AA, Skogvoll E, Spigset O. Effect of Proton Pump Inhibitors on the Serum Concentrations of the Selective Serotonin Reuptake Inhibitors Citalopram, Escitalopram, and Sertraline. Therapeutic Drug Monitoring 2015; 37: 90-97.

5. De Castro A, Femandez M, Laloup M, Samyn N, De Boeck G, Wood M, Maes V, Lopez-Rivadulla M. Highthroughput on-line solid-phase extraction-liquid chromatography-tandem mass spectrometry method for the simultaneous analysis of 14 antidepressants and their metabolites in plasma, J. Chromatog. A 2007; 1160: 3-12.

6. Weisskopf E, Panchaud A, Nguyen KA, Grosjean D, Hascoet JM, Csajka C, Eap CB, Ansermot N, S-BMS Collaborators. Simultaneous determination of selective serotonin reuptake inhibitors and their main metabolites in human breast milk by liquid chromatographyelectrospray mass spectrometry. J. Chromatogr. BAnalytical Technologies in the Biomed. and Life Sci. 2017; 1057: 101-109.

7. Pinto MAL, de Souza ID, Queiroz MEC. Determination of drugs in plasma samples by disposable pipette extraction with C18-BSA phase and liquid chromatography-tandem mass spectrometry, J. Pharmaceut. and Biomed. Anal. 2017; 139: 116-124.

8. Wylie FM, Torrance H, Anderson RA, Oliver JS. Drugs in oral fluid - Part I. Validation of an analytical procedure for licit and illicit drugs in oral fluid, Forensic Science International 2005; 150: 191-198.

9. Lacassie E, Gaulier JM, Marquet P, Rabatel JF, Lachatre $G$, Methods for the determination of seven selective serotonin reuptake inhibitors and three active metabolites in human serum using high-performance liquid chromatography and gas chromatography, J. Chromatogr. B 2000; 742: 229-238.

10. Togunde OP, Cudjoe E, Oakes KD, Mirnaghi FS, Servos MR, Pawliszyn J, Determination of selected pharmaceutical residues in wastewater using an automated open bed solid phase microextraction system, J. Chromatogr. A 2012; 1262: 34-42.

11. Mahmoud AM, Darwish IA, Khalil NY. Fluorometric Study for the Reaction Between Sertraline and 7-chloro-4nitrobenzo-2-oxa-1,3-diazole: Kinetics, Mechanism and Application for the Determination of Sertraline in Tablets, J. Fluorescence 2010; 20: 607-613. 
12. Das RS, Agrawal YK, Spectrofluorometric Analysis of New-Generation Antidepressant Drugs in Pharmaceutical Formulations, Human Urine, and Plasma Samples, Spectroscopy-an International Journal. 2012; 27: 59-71.

13. Sasajima $Y$, Lim LW, Takeuchi T, Suenami K, Sato K, Takekoshi $Y$, Simultaneous determination of antidepressants by non-aqueous capillary electrophoresis-time of flight mass spectrometry, J. Chromatogr. A. 2010; 1217: 7598-7604.

14. Chen XJ, Zheng SQ, Le J, Qian ZY, Zhang RS, Hong ZY, Chai YF, Ultrasound-assisted low-density solvent dispersive liquid-liquid microextraction for the simultaneous determination of 12 new antidepressants and 2 antipsychotics in whole blood by gas chromatography-mass spectrometry. J. Pharmaceut. and Biomed. Anal. 2017; 142: 19-27.

15. Rosado T, Goncalves A, Martinho A, Alves G, Duarte AP, Domingues $F$, Silvestre $S$, Granadeiro $L B$, Oliveira $V$, Leitao C, Gallardo E. Simultaneous Quantification of Antidepressants and Metabolites in Urine and Plasma Samples by GC-MS for Therapeutic Drug Monitoring, Chromatographia 2017; 80: 301-328.

16. Truta L, Castro AL, Tarelho S, Costa P, Sales MGF, Teixeira HM. Antidepressants detection and quantification in whole blood samples by GC-MS/MS, for forensic purposes, J. Pharmaceut. and Biomed. Anal. 2016; 128: 496-503.

17. Khalil NY, Mahmoud AM, Darwish IA, Al-Majed ARA. Highly Sensitive LC Method with Automated Co-Sense System and Fluorescence Detection for Determination of Sertraline in Human Plasma, Chromatographia 2010; 71: 825-831.

18. Costa IL, Machado CS, Pletsch AL, Torres YR. Simultaneous HPLC-PDA determination of commonly prescribed antidepressants and caffeine in sludge from sewage treatment plants and river sediments in the Itaipu reservoir region, Parana Brazil Intern. J. Environment. Anal. Chem. 2019; 10: 1-17.

19. El Defrawy AM, Saber AL. Spectrophotometric and theoretical studies on the determination of etilefrine hydrochloride in pharmaceutical formulations and biological samples. Trop J Pharm Res 2017; 16: 2487 2500.

20. Gorog S. Ultraviolet-Visible Spectrophotometry in Pharmaceutical Analysis; CRC Press Inc.: Florida, 1995; 27: 188-190.

21. Amin AS, El-Mossalamy MA, Killa HM, Saber AL. Three Spectrophotometric Methods for the Determination of Oxomemazine Hydrochloride in Bulk and in Pharmaceutical Formulations Using Bromocresol Green, Congo Red, and Methyl Orange. Analy. Lett., 2008; 41: 80-89,

22. Chen D, Jiang $S$, Chen $Y, H u Y$. HPLC determination of sertraline in bulk drug, tablets and capsules using hydroxypropyl- $\beta$-cyclodextrin as mobile phase additive. 2004; 34: 239-245.

23. Miller JC, Miller JN. Statistics in Analytical Chemistry", 3th Ed., Ellis Horwood, Chichester, 1993; chapter 3.

24. Taha A, Rücker G. Utility of $\pi$-Acceptors in Alkaloid Assay. Archiv der Pharmazie, 1977; 310: 485-494. 